\title{
An Investigation into the Impact of Performance Management Systems on Employee Productivity: The Case Study of Information and Communication Technologies (ICT) Companies in Harare, Zimbabwe
}

\author{
Nobuhle Ziyaminyana \\ MANCOSA Graduate School of Business, \\ 16 Samora Machel St, Durban Central, \\ Durban, 4001, SOUTH AFRICA \\ Mr. Oliver Pwaka \\ MANCOSA Graduate School of Business, \\ 16 Samora Machel St, Durban Central, \\ Durban, 4001, SOUTH AFRICA
}

\begin{abstract}
The study investigated the impact of performance management systems on employee productivity using a case study of information and communication technologies (ICT) companies in Harare. The major motivation to conduct the study was because of low employee productivity. The ICT sector, like many other sectors, is faced with a myriad of challenges including a high degree of competition in the market due to the entrance of new players in a dynamic business environment. The objectives of the study were to determine various impacts on productivity and make recommendations for appropriate performance management systems for the organisations. The study adopted a descriptive research design for the collection of primary data. Stratified sampling was adopted to ten organisations for the study. A sample of 312 respondents was selected from 1428 employees. The study concluded that performance appraisal did have an impact on employee productivity. Based on the conclusions, there is a need for the management and the governing committees to explain the value and importance of performance appraisal as well as management expectations from employees. This helps employees to have a buy-in from conception to completion; hence it would be natural for employees to adopt the system, as they will be part and parcel to the system. It is suggested that the Human Resources departments foster better working relationships with employees in order to educate and update them on requirements; hence general employee productivity will be improved.
\end{abstract}

Keywords: employee productivity; employee relationships; ICT sector.

DOI: $10.7176 / \mathrm{EJBM} / 11-3-04$

\section{INTRODUCTION}

The competitive business environment had been going through various changes that would need organisations to constantly reposition themselves through the reviews of performance management systems. More so, in the face of cut-throat competition, maintaining existing customers has not been quite enough for the long-term survival of organisations. As such, the study sought to investigate the impact of performance management systems on the productivity of employees concentrating specifically on the information and communication technologies (ICT) companies that are based in Harare.

\subsection{The background to the problem}

Increased competition in the global operating business environment had been forcing organisations to restrategize and re-think so as to maintain a competitive advantage in the business arena. Indeed, organisations in various sectors had been facing a myriad of challenges including a high degree of competition in the market due to the entrance of new players and the dynamic business environment (Jacobsen \& Andersen, 2014). This was also noted by Watkins and Leigh (2012), who opine that the market scenario in many business sectors has been characterised by uncertainty, ambiguity, complexity and volatility. Consequently, organisations had adopted performance management systems in order to improve their employee's productivity through various incentives. Amongst all other factors, performance management systems had been viewed as a catalyst for increasing employees' productivity in organisations (Jagoda, Lonseth \& Lonseth, 2013).

In Zimbabwe, the information, communication and technology (ICT) sector created a new competitive landscape in the last decade. However, the sector had been characterised by cut-throat competition due to the entrance of new players following the dollarization of the economy in 2009 (Machingambi, Maphosa, Ndofirepi, Mutekwe \& Wadesango, 2013; Zungura, 2014). Because of intense competition, there has been declining productivity in many organisations leading to high employee turnover intentions. According to Wachira (2013), 
an estimated $45 \%$ of the workforce in the information, communication and technology sector had left their jobs in search for "greener pastures". In fact, employee retention in the information, communication and technology industry had been the Achilles Heels for many organisations. The process of repeatedly hiring employees had also become costly to most of the organisations in the information, communication and technology sector. The organisations have come under increasing pressure to perform with few human and capital resources. In this regard, it has become indispensable for the organisations to continuously check employee performance and measurement and analyse the duties and tasks given to them. For many organisations in the information, communication and technology sector, the performance management system has become an important tool for enhancing and developing employee skills, which are lacking. Against this background, the study sought to determine the impact of performance management systems on employee productivity with particular reference to information and communication technologies companies, which are based in Harare.

\subsection{Statement of the problem}

In order for the information and communication technologies companies to successfully achieve their objectives and goals, there is the urgent need to focus on performance management systems, consistent absenteeism at work, lack of motivation and poor and unconducive working standards had been the other factors triggering poor performance by employees in the information and communication technologies organisations. Hence, it was the study's intention to investigate the impact of performance management systems on the productivity of employees for information and communication technologies companies in Harare.

\subsection{Research objectives}

In lieu of the discussed background to the study and the research problem, the study sought to achieve the following research objectives:

- To determine the impact of performance appraisal on the productivity of employees.

- To establish the impact of performance training and development on the productivity of employees.

- To determine the impact of rewards system on the productivity of employees.

- To determine the impact of performance appraisal feedback on the productivity of employees.

- To make recommendations for appropriate performance management systems for the organisations in the information and communications technology industry.

\subsection{Significance of the study}

It was hoped that the study would make meaningful contributions both to theory and practice. Findings from the study would assist management of companies in the information and communication technologies industry in providing clear indications of the behaviours required and not required to enhance employee productivity. More so, the findings would be of profound significance to senior management in forecasting through the use of various performance management systems for the improvement and betterment of their respective organisations. In addition, it is expected that findings from the study would help the management of the respective organisations in understanding how the use of performance management systems would improve employees' productivity and ultimately organisational performance and productivity. Furthermore, it is also expected that the study results would help the organisations in setting out their own tailor-made performance management systems that would suit the firms' mission, strategic goals and their nature of business operations. More significantly, results from the study would be important for ensuring that all employees would focus their skills and talent on their job responsibilities and this will help in the growth of the organisation.

From a theoretical perspective, the current literature on performance management systems and employee productivity shows an overwhelming geographical bias. Most empirical studies showing the impact of performance management systems on employee productivity have been carried out in countries such as Nigeria (Agha, \& Onyeizugbe, 2011; Salau, Oludayo \& Omoniy, 2014); Ghana (Idemobi \& Akam, 2010); Kenya (Gichuhi, Abaja \& Ochieng, 2014); Pakistan (Batool \& Zulfiqar, 2011; Safdar, Waheed \& Rafiq, 2011) and various Western countries (Colville \& Millner, 2011) where the level of technological development is significantly higher than in Zimbabwe. Accordingly, the study will seek to close this literature gap. The dearth of data also means that findings from the study may serve as a stimulus for further research. More so, the previous studies on the impact that performance management systems have on employee productivity have produced mixed and conflicting results, with many different variables being assessed. Scholars such as Batool and Zulfiqar (2011) and Gichuhi, Abaja and Ochieng (2014) established a positive correlation between performance management systems and employee productivity whilst Muhammad, Shahid, Muhammad and Ehtesham (2011) concluded that the relationship between these two variables was negative. These conflicting results call into question the need for further research on the subject. 


\section{LITERATURE REVIEW}

Daniels (2014) describes performance management as the changing behaviours, which seek to improve and ensure the effectiveness of an organisation. A similar definition by Chiang and Birtch (2010) view performance management as a process which seeks to measure and improve employee effectiveness. From the above definitions, it can be argued that performance management seeks to improve employee behaviour and performance in order to increase organisation productivity.

\subsection{Performance management system}

The definitions of performance management system abound. According to Boselie, Dietz and Boon (2015), performance management systems can be described as formal, information-based routines and procedures used by managers to maintain or change in the activities of an organisation. A similar definition by Dobre (2013) describes performance management system as various metrics that are used by organisations to measure the effectiveness and efficiency of employee actions. Performance management system is also described by Tripathi and Agrawal (2014) as the process of decision making used by organisations through collection, analysis and monitoring of information related to employee performance. From these definitions, it can be deduced that performance management systems are meant to collect employee information about their skills, abilities and potential. These will then be used in organisational workforce planning. As such, organisations use performance management systems to improve the quality and quantity of work done and bring all activity in line with an organisation's objectives.

\subsection{Theoretical foundations}

There are various theories which are used to explain the impact of performance management systems on employee productivity. However, the study was based on the expectancy theory by Vroom (1964) and the goal setting theory proposed by Edwin Locke (1968). These theories are outlined in the following sections.

\subsubsection{Expectancy theory}

The expectancy theory by Vroom (1964) is based on the argument that employees' efforts would result in performance and performance would lead to rewards. These rewards are either positive or negative and the more positive the rewards the more likely the employees will be highly motivated to perform at work (DeutschSalamon \& Robinson, 2011). On the other hand, the more negative the reward the less likely the employees will be motivated. Thus, the expectancy theory also postulates that employees' motivation towards an action is determined by perceptions that the type of action would result in a specific outcome. As noted by Hafiza, Shah, Jamsheed and Zaman (2011), employees are usually motivated to exert more effort in order to produce better results because of the expected rewards. The expectancy theory, on the other hand, argues that employee motivation can be determined by the expected outcome that will arise from the type of action (Vroom, 1964). Thus, it is the perception and preference by an individual on whether he or she will be able to get a specific outcome. In other words, expectancy theory indicates the chances of whether a particular action will result in desired outcomes and rewards (Selden \& Sowa, 2011). As such, employees will perform productively if they believe that there will be a positive reward for their efforts in an organisation.

The other assumption of the expectancy theory is that people usually join organisations with many expectations about their needs and past experiences (Kabak, Gocer, Kucuksoylemez \& Tuncer, 2014). Consequently, these affect how individuals react to the organisation because of their conscious choice. In many organisations, there is a need for performance management systems that would result in better performance of employees. According to Hunter and Nielsen (2013), performance management system variables may not result in the same levels of employee productivity. For instance, a reward policy does not necessarily result improved employee performance since some employees may view it as unfair (Kiechel, 2010). Thus, it is the job of management to evaluate its performance management systems and come up with policies that would result in improved employee productivity. Furthermore, the other assumption of the expectancy theory is that people would want different things from the organisation. For example, different people need different things such as good salary, career advancement, job security, promotion and other career challenges (Tripathi \& Agrawal, 2014). The study adopted the expectancy theory since it underlies the concept of performance management systems which state that employee performance is influenced by the expectations pertaining to future events. Expectancy theory applies to this study since it focuses on the differences between individuals and assumes that each and every individual will be motivated to perform better by their own prospects.

\subsubsection{Goal setting theory}

The goal setting theory emphasizes the important relationship between goals and performance. According to the theory, setting performance goals for employees is important for motivating them to work towards achieving these goals (Schultz, 2006). The theory also states that specific high goal would result in higher performance and that the higher the goals, the higher an employee's performance In this regard, assigned goals will influence employees' beliefs about being able to perform the tasks at hand and may be motivated to even increase their 
effort. If the performance improves, this will then result in the achievement of the performance management system (Latham, Borgogni \& Petitta, 2008). The main reason why goal setting has a positive effect on performance is that an employee is motivated to work hard when there is a reward at the end of the performance. Thus, it should be noted that the prime axiom of goal setting theory is that difficult goals would result in higher performance as employees would strive to "do their best" (Kabak, Gocer, Kucuksoylemez \& Tuncer, 2014).

The theory highlights four components which connect goals in order to have performance outcomes and these are difficulty, specificity, proximity and feedback. According to Cook and Crossman (2004), specific goals should be set for employees and this should drive their attention to priorities of achieving the goals. If the set goals are not achieved, there will be the need to either improve employee performance or modify the goals to make them more realistic.

The goal setting theory was used for the study because of its strong empirical basis, with an emphasis on the continuous process of employee development. In this regard, the theory can be a useful tool for analysing performance management and employee productivity in organisations. More so, various studies have incorporated the goal-setting theory into employee task performance and performance management systems (Kabak, Gocer, Kucuksoylemez \& Tuncer, 2014; Tripathi \& Agrawal, 2014).

\subsection{Concepts of performance management systems and employee productivity}

Employees in various organisations are required to perform tasks which are meaningful and also participate in the setting of goals as well as continuously developing their career goals (Dechev, 2010). In order to achieve these goals, it is of paramount significance to train employees so that they will perform productively (Madison, 2016). According to Singh, Kochar and Yüksel (2010), the key elements of a successful performance management system include leadership commitment, alignment of the performance management system and a culture of improving and identifying good performance. It should be noted that the success of every organisation is determined by the efficiency of the workforce in executing their respective duties and responsibilities. In this regard, it is the duty of every organisation to monitor the performance of every employee through the use of performance appraisal (Selden \& Sowa, 2011; Zungura, 2014). In this regard, it is the objective of performance appraisal to identify measures for the control of employee job performance. In addition, performance appraisal can be used by organisations as a tool for planning for employee development (Bahrija, Herzegovina \& Cebic, 2012). Performance appraisal can be used by organisations as a tool for setting up employee performance standards as well as expectations. Additionally, the performance management system is also of paramount significance for organisations in identifying possible strengths and weaknesses of employees across all departments (Jagoda, Lonseth \& Lonseth, 2013). Moreover, the use of standardised performance management system would allow organisations to have knowledge about the organisation's strengths, weaknesses, threats and opportunities in their human capital (Lambert, 2009).

\subsection{Impact of performance appraisal on the productivity of employees}

According to Ubeda and Santos (2013), performance appraisal can be described as activities which involve the assessment of individuals or other levels of performance with the objective of attaining organisational goals. Another definition by Shaukat and Surrayya (2013) describe performance appraisal as the process that seeks to contribute towards effective management of individuals in an organisation and also seeks to achieve high levels of organisational. As pointed out by Mohammad, Mehrzad, Mahmoud and Mohammad (2012), performance appraisal is a robust concept that covers various activities that are connected to the evaluation of employees and improvement of their capabilities, skills and abilities through development and adequate rewards. Important to note, performance appraisal is an important aspect for employee career development and this should be a continuous process that involves assessment and measurements for every employee's input to the organisation. Thus, a well-crafted performance appraisal system should be aligned with organisational goals and provide vivid, performance-based feedback to employees. The ultimate goal of the performance appraisal systems should be to increase employee motivation and productivity.

Previous empirical studies on the impact of performance appraisal on employee productivity have produced mixed and conflicting results. Scholars such as Batool and Zulfiqar (2011) and Gichuhi, Abaja and Ochieng (2014) established that there is a positive impact between performance appraisal and employee productivity. However, studies by Muhammad, Shahid, Muhammad and Ehtesham (2011) concluded that the impact of performance appraisal on employee productivity was negative. Esu and Inyang (2009) argued that the best performance appraisal is the one that is done every day although this is impossible. Another critic, Lambert (2009) argues that when managers are not skilled in performance appraisal then they will provide incorrect feedback in terms of productivity. Consequently, the whole performance appraisal process would be a negation. As postulated by Esu and Inyang (2009), the majority of the public sector businesses have failed dismally because of the use of ineffective performance appraisal systems that would end up demotivating employees. These conflicting results from the literature call into question the need for further research on the subject of the 
effect of performance appraisal on employee productivity.

\subsection{Impact of performance training and development on the productivity of employees}

Training and development are responsible for all issues relating to the development of employees, induction and coaching of the organisational mission and objectives (Demerouti \& Cropanzano, 2010). More significantly, training and development also provide insight on employee strengths and weaknesses (Selden \& Sowa, 2011). As pointed out by Agha and Onyeizugbe (2011), the success of any organisation would depend on the quality of its personnel and it is significant to have an effective performance management system that is able to identify employee-training needs. Effective training programs are paramount in the construction of a more conducive learning environment for the employees. Indeed, effective training and development programs would assist employees in getting acquaintance with any new technological advancement in the organisation as well as gaining competency needed to perform jobs and responsibilities. By linking training and performance to identified performance gaps in an organisation, training will then become focused, specific and relevant.

From the above discussion, it can be argued that training and development can be regarded as a way of sharpening and developing employees' thinking ability in order to make better decisions at the workplace and improve productivity. It can be concluded that if the training of employees in an organisation is well planned and designed, the performance and productivity gaps would be positively improved. In this regard, it can be argued that training and development provide a galaxy of benefits to both the employer and employees. As such, it is always of profound importance for organisations to align their training and development programs with the overall organisational strategy.

\subsection{Impact of rewards system on development on the productivity of employees}

The rewarding process of employees includes various dimensions such as personnel development, monetary rewards, non-monetary rewards and identifying the results or performance (Idemobi \& Onyeizugbe, 2011). Examples of financial rewards include bonus systems, salary, wages and perquisite whilst non-financial rewards include comfort of working place environment, certificates, authority and responsibility, promotion, education, participation to decisions, flexible working hours, social activities, vacation time, recognition and appreciation (Salau, Oludayo \& Omoniy, 2014). Both financial and non-financial rewards help employees in staying in the organisations for a long period of time. In other words, if rewards are not provided, employees will be forced to leave the organisation. Some employees like receiving intrinsic rewards such as praise and recognition for higher accomplishments, while other employees are satisfied with extrinsic rewards such as salaries and monetary incentive offered to employees (Lawler, 2008).

There has been a brisk academic debate on the impact of rewards management system on employee productivity. Scholars such as Akhtar and Khattak (2013) strongly argue that reward systems are important catalysts for motivating employees to efficiently use their skills in pursuing organisational goals and objectives. Thus, rewards are regarded as important mechanisms for aligning employee behaviours to suit organisational interests. In relation to the above findings, Ajila and Abiloa (2004) concluded that rewarding employees would result in improved organisational performance since every employee would want to be recognized for performing outstanding work. In the same vein, Aktar (2012) postulate that employees who are rewarded usually perform better than those that are not. Therefore, rewards play a significant role in the success of the organisation.

\subsection{Impact of performance appraisal feedback on the productivity of employees}

Performance appraisal feedback involves communicating back by the supervisors to their subordinates after an appraisal has been done (Tahir, Khan, Israr, Jan, Hashim \& Muhammad, 2014). It is a crucial activity to provide employees with performance feedback as this will encourage and enable self-development. According to Aarti, Seema, Bhawna and Jyoti (2013), one of the most important conditions in performance appraisal is to provide employees with clear, performance-based feedback. As elucidated by Bahrija, Herzegovina and Cebic (2013), performance feedback mechanisms are important for identifying employee strengths and weaknesses. As such, organisations need to continually inform their employees of their values, strengths and also recognize them for jobs well done. Whenever a mistake is detected, remedial steps will be immediately taken and reduce loss to the organisation. Thus, the provision of performance appraisal feedback is important as this can influence the future performance of the employees. As noted by Gichuhi, Abaja and Ochieng (2014), good performance appraisal feedback mechanisms would help employees in knowing how they would be progressing within in the organisation in terms of carrying out their duties, tasks and responsibilities. As such, performance appraisal feedback should not be delayed but should be timely and specific.

According to Stone, Stone- Romero and Lukaszewski (2006), when employees do get feedback on their performance they will be motivated to become more innovative and come up with brilliant ideas that would provide the organisation with a competitive advantage. Moreover, the employees will realise that putting more 
effort in their duties in responsibilities would reward them with monetary and non-monetary benefits.

A longitudinal study by Brown and Edmunds (2011) found that performance appraisal feedback leads to good employee performance and engagement in the organisation. Hafiza, Shah, Jamsheed and Zaman (2011) examined over 664,000 employees from more than 80 companies around the world and concluded that employees productivity improved by $40 \%$ for those with higher levels of performance appraisals and feedback, whereas productivity decreased by $28 \%$ for companies with lower levels of performance appraisals and feedback.

\subsection{Empirical studies}

There are various empirical studies which have been conducted to investigate the impact of performance management systems and employee productivity. A study by Danish and Usman (2010) to determine the impact of performance management systems from both private and public sectors organisations in Pakistan found that performance management systems positively impacted on employee productivity and motivation.

Randell (2014) in a study of the relationship between performance management systems and employee productivity of 2000 employees of insurance companies in the Western Cape, it was found out that there was a positive relationship between performance management systems and employee productivity. The study concluded that organisations should review their current performance management systems in order to ensure higher employee motivation and productivity.

\subsection{Conceptual framework}

The conceptual framework for this study has been developed from the reviewed literature relating to the impact of performance management systems and employee productivity. The researcher designed the conceptual framework in figure 2.1 which depicts the relationships between independent and dependent variables since they depend on each other. From the study's conceptual framework, employee productivity can be measured in terms of the number of customers served, customer relations, quality of work, punctuality and customer care. On the other hand, performance management systems are measured in terms of performance appraisal, training and development, rewards system and performance appraisal feedback. The following diagram illustrates the study's conceptual framework.

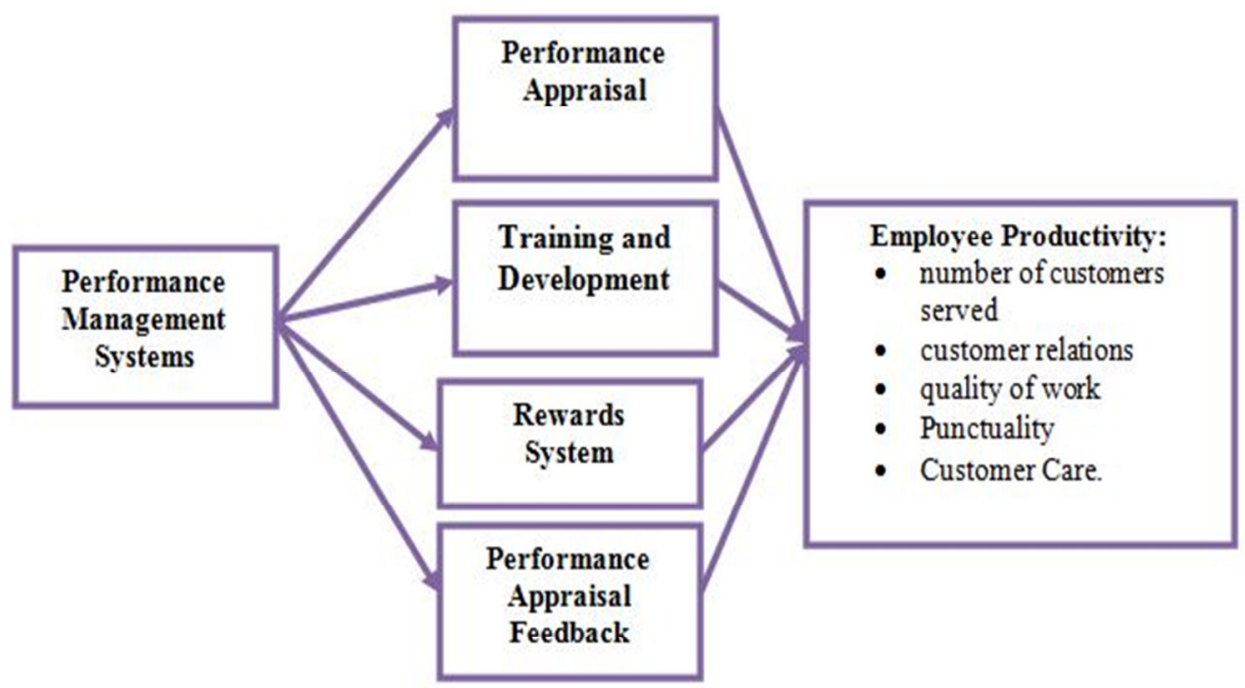

Figure 2.1 Conceptual Framework

As indicated in figure 2.1 above in the conceptual framework, the independent and dependent variables are interrelated and there is no way these can be separated. The dependent variables are variables that the researcher measures in order to establish the impact created on them (Salau, Oludayo \& Omoniy, 2014). The dependent variable usually waits for the effect of an independent variable. For example, in this study, performance appraisal, training and development, rewards system and performance appraisal feedback are the independent variables resulting to employee productivity which is the dependent variable because it relies on the effects of the four.

\subsection{Research gap}

Conceptually, the literature on the impact of performance management systems dimensions on employee productivity offered inconsistent and inconclusive results. In particular various scholars collided in proving the impact of rewards system on development on the productivity of employees (Idemobi \& Onyeizugbe, 2011; Lawler, 2008). Thus, the study will seek to provide a conclusive answer on the impact of rewards system on 
development on the productivity of employees. Although there is a voluminous literature on the impact of performance management systems dimensions on employee productivity there is scarce data in the context of Zimbabwe. Given this context, it is imperative that in Zimbabwe the impact of performance management systems dimensions on employee productivity needs to be investigated. Zimbabwe is culturally and economically different from the Asian, United States of America and other developed western European countries (Aarti, Seema, Bhawna \& Jyoti, 2013; Farooqui \& Nagendra, 2014; Shaheen, Naqvi \& Khan, 2013). Thus, intuitively the perceived impact of performance management systems dimensions on employee productivity in the Zimbabwean context might not be exactly the same for that of the employees in developed countries. Therefore, this will immensely contribute to the extant body of knowledge in this emerging field and a literature review needs to be conducted to determine the impact of a performance management system. In this regard, this study concentrated on the information and telecommunication sector to find out the impact performance management system had on employees' productivity.

\section{RESEARCH METHODOLOGY}

Descriptive research designs are premised on objectivity as well as the ability to create, manipulate and control variables (Rubin \& Babbie, 2010; Saunders, Lewis \& Thornhill, 2012). The study adopted a descriptive research design since it suited the research objectives. Moreover, a descriptive research design was used for the collection of primary data from respondents because it would help in saving time, reducing costs and improving the amount of quality information yielded is valid. In addition, a descriptive research design would reduce researcher bias and maximize the reliability of the primary data collected (Collis \& Hussey, 2011). Furthermore, descriptive research was used for the study because of its ability to explore more in detail about employee productivity and performance management systems. Thus, the research design fitted the study of this nature since the researcher wanted to look at the effect of the independent variables (performance management systems) on the dependent variable (employee productivity). Furthermore, the descriptive research designs could help the researcher to identify demographic characteristics of the respondents (Hair, Babin, Money \& Samouel, 2011). In this regard, the use of descriptive research design could help the researcher to have a better understanding of issues relating to performance management systems and employee productivity for the information, technology and communications organisations under study. The other reason for using descriptive research design was to collect detailed and factual information. The intention of the study was to collect primary data at a particular point in time, which would be used to describe the nature of existing conditions. Furthermore, a descriptive research design was chosen for the study because of its relevance in answering research questions such as "what", "who", "when" and "where" (Bryman \& Bell, 2011).

\subsection{Research philosophy}

The study used positivism for the study since the results would be objective, reliable and could be generalised to many different research populations as suggested by Brown and Edmunds (2011) and Wiid and Diggines (2011). More so, the study was purely quantitative that had a conceptual framework comprising of independent and dependent variables derived from the study objectives. Important to note, since the study intended to investigate the impact of performance management systems variables and employee productivity, use of positivism would show whether the impact was significant enough for the organisation under study. As such, positivism would show the correlations between variables. More significantly, a positivist quantitative research inquiry would assist the researcher in expanding more output thereby minimizing researchers' biases. Thus, a positivist approach would provide a self-corrective tool, which checked data credibility and reduced distortions due to personal subjectivism. Above all, the quantitative research methodologies would seek to describe the general demographic characteristics of the respondents and draw a large and representative sample from the study population (Rubin \& Babbie, 2010).

\subsection{Target population}

According to Oppenheim (2014), a target population is the total number of all individuals with certain similar characteristics that are of interest to the researcher. This study was focused on performance management systems of information and communication technologies companies in Harare. In particular, the study focused on 10 organisations in Harare. These organisations in Harare have a staff complement of 1428 employees and management (Techzim, 2017). The population had the characteristics and the potential of providing the relevant information regarding the impact of performance management systems on employee productivity. The researcher had to focus on the employees and management who had information relating to the impact of performance management systems on employee productivity. In addition, the employees and management had the required first-hand information relating to all the research questions. It was expected that the 10 organisations selected would allow for an in-depth investigation into the impact of performance management systems on employee productivity as well as any challenges being faced by the respective organisations in the implementation of this 
aspect.

For the purposes of this study, structured questionnaires were used for the collection of primary data. Structured questionnaires were chosen for the study because of their easiness to analyse and quickness to administer. Moreover, the use of questionnaires is cost-effective in terms of time, human resource and costs, as they require minimal resources but covers a large sample. The other benefits of the use of questionnaires for the study were that they allowed the research to collect a huge amount of primary data from the ICTs companies within a short time period. Above all, the questionnaire helped the researcher in maintaining study objectivity and allowed the participants to freely express their perceptions regarding performance management systems. Furthermore, the questionnaires allow the busy respondents to complete the questionnaires when they would be free.

\subsection{Pilot study}

A pilot study is a "rehearsal" or trial run of a full study. It is also known as a pre-test of research instruments such as interview schedules or questionnaires (Bryman \& Bell, 2011; Saunders, Lewis \& Thornhill, 2012). The researcher conducted a pilot study before full distribution to all the respondents in order to validate the research instrument. Thus, the study's pilot study acted as the feasibility study for pre-testing the research instruments. As such, the researcher distributed the questionnaires to a total of 10 participants ( 5 supervisors and 5 subordinates) who were randomly selected. The participants who were selected for the pre-test were later on not included in the survey. After the pilot study, the researcher had to make relevant adjustments with regard to logic, ambiguity and easy to understand. In particular, all questions regarded by the respondents as misleading were deleted.

\subsection{Data analysis}

Since the collected data was largely numerical in nature, the researcher had to use quantitative methods of data analysis. In particular, descriptive and inferential analytical methods were used for analysing data in relation to the research objectives. Statistical Package for Social Sciences (SPSS) version 24 was used to generate the statistics. The computer software provides extensive data handling capability and numerous statistical analyses from small to very large data statistics (Denzin \& Lincoln, 2011). In the report, documentary data was organized and presented in the form of tables and percentages. Descriptive statistics such as measures of central tendency and dispersion were used in describing the sample data in order to show the general response pattern. In particular, descriptive statistics helped in generating percentages, mean scores, standard deviations and frequencies. Frequency distributions could predict how many people or what percentage of people was in favour of a particular idea. These were then presented using tables, pie charts and bar graphs for easier interpretation. Pearson's correlation analysis was adopted for the assessment of the relationship between the independent variables.

\subsection{Validity and reliability}

According to Kitchenham and Pfleeger (2012), validity can be described as the degree to which a research instrument will be in a position to measure what it is supposed to measure. Reliability, on the other hand, seeks to determine how the research instrument will be a consistent measure (Denzin, \& Lincoln (2011).

The researcher empirically assessed the reliability of measures and the survey through the use of test-retest reliability method. The method sought to measure the degree to which all parts of the test would equally contribute to what was being measured (Kothari, 2011). That was done by comparing the results of one half of the test with the other results from the second half. If both halves of the test provided congruent results this would mean that the study's test had internal reliability. More so, that involved asking the questions only once. Additionally, the use of self-administered questionnaires enabled the researcher to measure the internal consistency of the constructs.

\subsection{Limitations of the study}

For ancillary staff, some questionnaires were filled in by the researcher or in some cases the liaison officers due to literacy issues. This brought into question the issue of subjectivity since someone else on the questionnaire captured what the respondents expressed verbally. Responses then became subject to the interpretation of the researcher or liaison officer.

\subsection{Elimination of bias}

In order to achieve responses that is almost representative of the ICT sector, the researcher tried by all means to incorporate ancillary staff, middle, and top management. A mixture of large corporates and small companies were considered for the study. No gender-specific questions were used in the questionnaire in order to avoid gender bias in the tabulation of results. The age range covered by the questionnaire was 20 years to 51 and above in order to more or less represent the general Zimbabwean workforce. 


\subsection{Ethical considerations}

There are various ethical concerns that needed to be considered by the researcher prior to conducting the survey study. These guidelines had to do with the voluntary participation of respondents, harm to respondents, as well as participants' anonymity and confidentiality (Collis \& Hussey, 2011). These guidelines are addressed and explained below as the researcher sought to help eliminate any ethical concerns.

\subsubsection{Ensuring participants were given an informed consent}

Study participants were requested to sign a letter giving consent to participate in the study. This was in order for them to be armed with the proper information before agreeing to be part of the study.

\subsubsection{Ensuring no harm to participants}

The researcher avoided potentially harmful questions. The identity of the participants was kept secret in order to avoid future repercussions as a result of the outcome of the study. The researcher promised confidentiality and did not ask for the names of the respondents. In line with Gilgun (2014), all the study respondents were assured that the primary data obtained from the study would be kept confidential and hence they could feel confident to express their opinion without fear and concern. The researcher ensured that the anonymity of the participants was maintained through the removal of any identifying characteristics before the dissemination of information. It was also assured that all collected data would be analysed and reported only in aggregate form.

Before the distribution of the questionnaire, all the participants were informed of the purpose, nature and data collection methods. In addition, the researcher also explained the roles for the respondents and the researcher. In line with this, the researcher first obtained the consent from the respondents in writing. Despite all the above-mentioned precautions, it was made clear to the participants that the research was for academic purpose only and their participation was absolutely voluntary. The researcher also provided contact details and personal email in case there were concerns which wanted to be raised during the research.

\subsubsection{Ensuring confidentiality and anonymity}

The identity of the participants was kept anonymous throughout the study. It was emphasized that there was no need for the study participants to write their names on the questionnaire.

\subsubsection{Ensuring permission is obtained}

From the onset, permission was sought from MANCOSA, as well as to the concerned companies in the ICT sector in Harare. A letter of consent was given to participants in order to get their permission to conduct the study.

\section{RESULTS}

A total of 312 questionnaires were distributed to the respondents. From the distributed questionnaires, a total of 188 were fully completed and returned and that represented a response rate of $60.26 \%$. The above response rate of $60.26 \%$ was considered high and representative enough to proceed with further analysis and data interpretation as well as generalizing the findings to the ICT companies. This was in agreement with Creswell (2013) who postulates that a response rate above $50 \%$ is statistically acceptable to make generalised responses for a sample size between 300 and 350 with a margin of error of 5\%. Based on these suggestions by scholars, it can be argued that the study's response rate of $60.26 \%$ was good a good basis for making conclusions and recommendations.

\subsection{Demographic characteristics of respondents}

The researcher sought preliminary information on the characteristics of the study respondents. In this regard, the study's demographic data focused on gender, academic qualifications, gender and number of years in their respective organisations.

According to the survey findings, a total of $54 \%$ were males, whereas $46 \%$ were females. It can be deduced that male employees and management largely dominated the ICT companies under study. These findings corroborate Gichuhi, Abaja and Ochieng (2013) who found that more than $75 \%$ of employees in the information and communication technology sector are males. This can be attributed to lack of gender mainstreaming in the technology industry. However, it is important to note that the gap in gender representation for the chosen sample was relatively small and therefore did not result in any implication on the impact of performance management systems on employee productivity.

The respondents were asked to state their age categories. According to the survey findings, $18 \%$ were in the age range 20 to 29 years old, $29 \%$ were in the age range 30 to 39 years and $33 \%$ were in the age range 40 years to 49 years. The study also revealed that $10 \%$ of the total respondents fell within 50 years and 59 years age category. It can be inferred that majority $(57 \%)$ of the employees in the ICT companies were aged between 20 years and 39 years which resulted in a mean age of 31.8 years. This implies that many of the employees in the ICT companies under study were young but old enough to respond to questions relating to the impact of performance management systems on employee productivity. Moreover, these employees were within the economically active zone for the country's population and this might indicate that organisations under study 
prefer employing youths who are more productive As such; it can be argued that most of the employees were young and energetic since information technology is very technical and requires agile individuals (Gupta \& Upadhyay, 2012). At the same time, it has been pointed out by Martinho, Gomes, and Mahmoud (2015) that the age group 20 years to 40 years is influenced by organisational events such as participation and acceptance of performance appraisal.

\subsubsection{Academic qualification of the respondents}

According to the survey findings, $21 \%$ of the respondents had diplomas whilst $35 \%$ were holders of bachelor's degrees. The survey also revealed that $26 \%$ had masters' degrees and $18 \%$ had doctorate degrees. The findings reveal that the majority of the respondents $(79 \%)$ had at a minimum of an undergraduate degree. This indicates that the respondents were highly educated to understand issues relating to the impact of performance management systems on employee productivity. Additionally, the high educational qualifications do show that the respondents were able to understand the contents of the questionnaire thereby making it easy to administer the questionnaires.

\subsubsection{Length of service in the organisations}

Regarding the time served in the respective organisations by the employees, the survey findings revealed that $10 \%$ of the respondents had been employed by their respective organisations for less than 1 year and a total of $15 \%$ for between 1 year and 3 years. Additionally, 22\% of the respondents had been with their respective companies for between 4 years and 6 years, 36\% for between 7 years and 9 years and $22 \%$ for more than 10 years. The above findings indicate that the majority of the employees had served their respective organisations for a period of at least 4 years. This shows that the respondents were experienced and possessed the necessary understanding of the impact of performance management systems on employee productivity in their respective organisations. At the same time, the length of service will also show a forceful effect on how the employees perceive performance management systems and performance appraisals since they would have been appraised for many times.

\subsection{Presentation of findings}

\subsubsection{Impact of performance appraisal on the productivity of employees}

According to the descriptive statistics, the statement "performance appraisal makes me work harder than expected" had the highest mean score of 4.849 and standard deviation of 0.260 . The statement "performance appraisal process encourages co-operation" which had a mean score of 4.572 and a standard deviation of 0.021 followed this. The statement "The performance goals set by the appraiser for me are in alignment with my career aspirations" had the lowest mean score of 3.570 and a standard deviation of 0.213 . Basically, the mean scores on statements relating to how performance appraisal affects employee productivity were larger than 4.000 indicating that the responses were slanted towards an agreement. Additionally, the standard deviation values were less than 1, indicating that this was a normal distribution and the distribution of individual data was close to the mean value. The table below shows the descriptive statistics pertaining to how performance appraisal affects employee productivity.

Table 4.1 Descriptive statistics: Impact of performance appraisal on the productivity of employees

\begin{tabular}{|c|c|c|c|c|}
\hline $\mathrm{N}$ & Min & Max & Mean & $\begin{array}{l}\text { Std. } \\
\text { Deviation }\end{array}$ \\
\hline $\begin{array}{l}\text { Performance goals set by the appraiser for me188 } \\
\text { are in line with my career }\end{array}$ & 1.00 & 5.00 & 3.570 & .213 \\
\hline $\begin{array}{l}\text { Performance appraisal makes me work harder } 188 \\
\text { than expected }\end{array}$ & 1.00 & 5.00 & 4.849 & .260 \\
\hline $\begin{array}{l}\text { Performance appraisal process encourages } 188 \\
\text { cooperation }\end{array}$ & 1.00 & 5.00 & 4.573 & .174 \\
\hline $\begin{array}{l}\text { Manager rates all employees on average rather } 188 \\
\text { than high or low to prevent controversy among } \\
\text { employees }\end{array}$ & 1.00 & 5.00 & 4.427 & .142 \\
\hline $\begin{array}{l}\text { There is sufficient training provided on } 188 \\
\text { performance appraisal systems }\end{array}$ & 1.00 & 5.00 & 4.571 & .021 \\
\hline Valid N (listwise) & & & & \\
\hline
\end{tabular}

From the descriptive statistics, it can be inferred that the employees in the ICT companies have not been able to set performance goals in line with employee career goals and objectives (mean $=3.570)$. However, the descriptive statistics indicated that performance appraisal has made employees work harder than expected (mean 
$=4.849)$ and encouraged cooperation between supervisors and supervisees (mean $=4.573$ ). In addition, the employees seem to agree that training of supervisors on the performance appraisal system had been sufficient $($ mean $=4.571)$. However, a point of concern has been that the managers have been accused of rating most employees on average in order to prevent controversy among employees (mean $=4.427$ ).

However, the study showed that performance goals had not been in line with employee career goals and objectives. As pointed out by Wachira (2013), performance appraisals should be in line with employee career goals and objectives in order to improve work performance and overall business performance. This suggests that appraisal not aligned with employee career goals can negatively impact on employee productivity in the organisations. Thus, effective performance appraisal systems have the ability to enhance the interests and performance of the workers culminating in the completion of specified performance targets and targets and attainment of specified performance goals.

\subsubsection{The impact of performance training and development on the productivity of employees}

Respondents were asked as to whether performance training and development of supervisors helped them in improving in their job performance. From the findings, $4 \%$ strongly disagreed, $11 \%$ disagreed and $9 \%$ remained neutral. In addition, $35 \%$ agreed and $41 \%$ strongly agreed with the view that performance training of supervisors helped the respondents improve their job performance.

In accordance with the above findings, it can be inferred that a greater number of the participants concurred that performance training of supervisors was paramount in improving their job performance. The findings can be interpreted as critical to the organisations in implementing performance-training programs in the organisations. A greater part of the respondents agreed with the assertion on the issue.

Descriptive statistics were also used to ascertain the impact of performance training and development on the productivity of employees. From the findings, the item "proper training and retraining of supervisors on appraisal will improve performance evaluation of employees" had the highest mean score of 4.714 and a standard deviation of 0.801 . The statement "training and retraining of supervisors eliminate performance problems" which had an average score of 4.643 and a standard deviation of 0.172 followed this. The statement "I have confidence on skills and capabilities of appraiser" had the lowest mean score of 4.287 and a standard deviation of 0.172 . Interestingly, most of the mean scores for the statements relating to the relationship between performance training and employee productivity were more than 4.000. This suggests that the majority of the responses were inclined towards an agreement. Additionally, the standard deviation values were not more than 1 indicating that the findings were normally distributed and the responses from the participants were very close to the mean value. The table below shows the descriptive statistics relating to the relationship between performance training and employee productivity.

Table 4.2 Descriptive statistics: Impact of performance training and development on the productivity of employees

\begin{tabular}{|c|c|c|c|c|}
\hline $\mathrm{N}$ & Min & Max & Mean & $\begin{array}{c}\text { Std. } \\
\text { Deviation }\end{array}$ \\
\hline $\begin{array}{l}\text { Performance management helps me develop } 188 \\
\text { key competencies in my work. }\end{array}$ & 2.00 & 5.00 & 4.451 & .047 \\
\hline $\begin{array}{l}\text { I have confidence on skills and capabilities of } 188 \\
\text { appraiser }\end{array}$ & 2.00 & 5.00 & 4.287 & .711 \\
\hline $\begin{array}{l}\text { Proper training and retraining of supervisors } 188 \\
\text { on appraisal will improve performance } \\
\text { evaluation of employees }\end{array}$ & 1.00 & 5.00 & 4.714 & .801 \\
\hline $\begin{array}{l}\text { training and retraining of supervisors } 188 \\
\text { eliminate performance problems }\end{array}$ & 1.00 & 5.00 & 4.643 & .172 \\
\hline Valid N (listwise) & & & & \\
\hline
\end{tabular}

As depicted from the above table, a relatively high number of responses were slanted towards an agreement. In particular, the descriptive statistics showed that training in performance management has the potential to develop key competencies in employees work (mean $=4.451)$. In addition, the findings also indicated that proper training and retraining of supervisors on appraisal issues would positively improve performance evaluation of employees resulting in increased productivity (mean $=4.714)$. Moreover, the survey findings also showed that training and retraining of supervisors would eliminate performance problems (mean $=4.643$ ) and also provide confidence on skills and capabilities of both appraisers and appraises (mean $=4.287$ ).

\subsubsection{The impact of rewards system on the productivity of employees}

With regard to the impact of rewards system on the productivity of employees, the statement "the benefits such as rent, clothing increase the loyalty to the organisation and success at work" had the highest mean score of 
4.722 and a standard deviation of 0.406 . The statement "rewarding mechanism positively affects the performance of employees at the workplace" was next, which had a mean score of 4.679 and a standard deviation of 0.114 . Likewise, the statement "appreciations by managers increase employee performance and commitment" had the lowest mean score of 4.074 and a standard deviation of 0.470 . Generally, all the statements relating to the influence of performance appraisal rewards on employee productivity had mean scores, which were more than 4.000, which suggest that the responses were slanted towards an agreement. At the same time, the standard deviation values, which were less than 1, indicate that the findings were normally distributed and the responses from the participants were very close to the mean value. The table below shows the descriptive statistics relating to the influence of performance appraisal rewards on employee productivity.

Table 4.3 Descriptive statistics: The impact of rewards system on the productivity of employees

\begin{tabular}{l|r|r|r|r|r|}
\hline $\begin{array}{l}\text { Rewarding mechanism positively affects the188 } \\
\text { performance of employees at workplace }\end{array}$ & 1.00 & 5.00 & 4.679 & $\begin{array}{c}\text { Std. } \\
\text { Deviation }\end{array}$ \\
$\begin{array}{l}\text { The benefits such as rent, clothing increase the loyalty } 188 \\
\text { to the organization and success at work. }\end{array}$ & 2.00 & 5.00 & 4.722 & .114 \\
$\begin{array}{l}\text { My success at work is being appreciated by the188 } \\
\text { manager through monetary and non monetary benefits. }\end{array}$ & 1.00 & 5.00 & 4.601 & .149 \\
$\begin{array}{l}\text { Promotion opportunities affect my performance at188 } \\
\text { workplace }\end{array}$ & 1.00 & 5.00 & 4.578 & .032 \\
\hline $\begin{array}{l}\text { appreciation by managers increases employee188 } \\
\text { performance and commitment }\end{array}$ & 1.00 & 5.00 & 4.074 & .470 \\
\hline \begin{tabular}{l} 
Valid N (listwise) \\
\hline
\end{tabular} & 188 & & & & \\
\hline
\end{tabular}

From the findings above, it can be deduced that reward systems such as rent, clothing can increase employee loyalty to the organisation and success at work (mean $=4.722$ ). The descriptive statistics also revealed that their success at work was being appreciated by their respective managers through monetary and nonmonetary benefits $($ mean $=4.601)$ and promotion opportunities (mean $=4.578$ ). Additionally, the descriptive statistics showed that general appreciation by managers increased employee performance and commitment $($ mean $=4.074)$.

\subsubsection{The impact of performance appraisal feedback on the productivity of employees}

The researcher sought to probe the impact of performance appraisal feedback on employee productivity. According to the findings, the statement "I get feedback on my evaluation and this enhances openness and performance parameters" had the highest mean score of 4.718 and a standard deviation of 0.317 . The item "manager communicates with me frequently about my performance" with a mean score of 4.707 and a standard deviation of 0.075 followed this. The statement "performance appraisal feedback makes me understand what I am supposed to be doing" had the lowest mean score of 4.244 and a standard deviation of 0.371 . Basically, the statements relating to the impact of performance appraisal feedback on employee productivity had mean scores, which were more than 4.000 and this suggests that the responses were slanted towards an agreement. At the same time, the standard deviation values, which were less than 1, indicate that the findings were normally distributed and the responses from the participants were very close to the mean value. The table below shows the descriptive statistics relating to the impact of performance appraisal feedback on employee productivity.

From the survey findings, it can be stated that performance appraisal feedback has been crucial in making employees understand what they are supposed to be doing (mean $=4.244)$. Additionally, it was also revealed that management had been instrumental in communicating with employees frequently about their performance (mean $=4.707)$. The study also showed that employees got feedback of their evaluation and this enhances openness, performance parameters $($ mean $=4.718)$ and translated to improved productivity $($ mean $=4.704)$.

\subsection{Correlation analysis}

To get an understanding of the impact of performance management systems on employee productivity for the ICT companies in Harare, the researcher used Pearson correlation analysis. This was in line with Cresswell (2013) who suggests that a correlation matrix can be used to measure relationships between independent and dependent variables in a given study. The correlation variables, which were used to determine the relationship between variables, ranged from -1 to +1 . The absolute value of -1 indicated that the association between the two variables is negative. On the other hand, an absolute value of +1 sign indicated that there is a positive correlation between two independent and dependent variables. If the correlation coefficient equal to 0 , this would mean that the relationship between the study variables is very weak. From the findings, performance appraisal has a significant association with employee productivity. In particular, performance appraisal has a positive and significant relationship with employee productivity with a correlation coefficient of $r=0.730$. This invariably implies that if the organisations significantly improve performance appraisal, then employee productivity will also equally increase. 
Regarding the relationship between performance training and employee productivity, the correlation coefficient of $r=0.677$ showed a positive relationship between the variables at $5 \%$ level of significance. More so, the $\mathrm{p}$ value of 0.001 showed that the relationship between performance training and employee productivity was significant. These findings invariably imply that the more pricing performance training programs conducted by the ICT companies for the better employee productivity will improve.

Performance appraisal rewards showed a positive correlation with employee productivity with a correlation value of 0.778 at $5 \%$ level of significance. These results imply that organisations with superior performance appraisal rewards are able to have improved employee productivity.

Performance appraisal feedback showed a positive and significant relationship with employee productivity with a correlation of $\mathrm{r}=0.752$ at $5 \%$ level of significance. The findings imply that performance appraisal feedback may contribute to improved employee productivity. More so, the $\mathrm{p}$ value of 0.001 showed that the relationship was significant. The findings mean that the more the organisation improves its performance appraisal feedback the better will be employee productivity.

\subsection{Regression analysis}

The researcher used multiple regression analysis to determine the impact of performance management systems on employee productivity for ICT Companies in Harare, Zimbabwe. In the regression model employee productivity was considered as the dependent variable. From a practical perspective, the findings suggest that the organisation can improve employee productivity by improving performance appraisal, performance training, performance appraisal rewards and performance appraisal feedback.

\section{CONCLUSION AND RECOMMENDATIONS}

The primary research led to the following findings in line with the research objectives:

\subsubsection{Determine the impact of performance appraisal on the productivity of employees}

Performance appraisal was contributing insignificantly in ensuring that employees increase their productivity. In particular, the descriptive statistics pointed out that the employees in the ICT companies have not been able to set performance goals in line with employee career goals and objectives (mean $=3.570)$. In addition, the study revealed that performance appraisal has made employees work harder than expected (mean $=4.849)$ and encouraged cooperation between supervisors and supervisees (mean $=4.573)$. In addition, the employees seem to agree that training of supervisors on the performance appraisal system had been sufficient $($ mean $=4.571)$. However, a point of concern has been that the managers have been accused of rating most employees on average in order to prevent controversy among employees (mean $=4.427$ ).

\subsubsection{Establish the impact of performance training and development on the productivity of employees}

It was established that the greater part of the respondents participated in training and development in different organisations during the past five years. From the findings, it was found that majority of the participants (76\%) concurred that performance training of supervisors was paramount in improving their job performance. The findings can be interpreted as critical to the organisations in implementing performance-training programs in the organisations. The descriptive statistics also showed that training in performance management has the potential to develop key competencies in employees work (mean $=4.451)$. In addition, the findings also indicated that proper training and reorientation of supervisors on appraisal issues would positively improve performance evaluation of employees resulting in increased productivity (mean $=4.714)$. Moreover, the survey findings also showed that training and retraining of supervisors would eliminate performance problems $($ mean $=4.643)$ and also provided confidence on skills and capabilities of both appraisers and appraisees (mean $=4.287$ ).

Regarding the impact of performance training and development on employee productivity, the correlation coefficient of $\mathrm{r}=0.677$ showed a positive relationship between the variables at $5 \%$ level of significance. More so, the $p$ value of 0.001 showed that the relationship between performance training and employee productivity was significant. These findings invariably imply that the more performance training programs conducted by the ICT companies the better employee productivity will improve.

\subsubsection{Determine the impact of rewards system on the productivity of employees}

From the findings above, it was found that reward systems such as a housing allowance and a clothing allowance could lead to an improvement in employee loyalty to the organisation and success at work (mean $=4.722)$. The descriptive statistics also revealed that their success at work was being recognised by their respective managers through monetary and non-monetary benefits (mean $=4.601)$ and promotion opportunities $($ mean $=4.578)$. Additionally, the descriptive statistics showed that general appreciation by managers increased employee performance and commitment (mean $=4.074)$. Performance appraisal rewards system showed a positive correlation with employee productivity with a correlation value of 0.778 at $5 \%$ level of significance. These results imply that organisations with superior performance appraisal rewards are able to have improved employee productivity. 


\subsubsection{Determine the impact of performance appraisal feedback on the productivity of employees}

From the survey findings, it was revealed that performance appraisal feedback has been crucial in making employees understand what they are supposed to be doing (mean $=4.244)$. Additionally, it was also revealed that management had been instrumental in communicating with employees frequently about their performance (mean $=4.707)$. The study also showed that employees got feedback of their evaluation and this enhances openness, performance parameters $($ mean $=4.718)$ and translated to improved productivity $($ mean $=4.70)$.

Performance appraisal feedback showed a positive and significant relationship with employee productivity with a correlation of $r=0.752$ at $5 \%$ level of significance. The findings imply that performance appraisal feedback may contribute to improved employee productivity. More so, the $\mathrm{p}$ value of 0.001 showed that the relationship was significant. The findings mean that the more the organisation improves its performance appraisal feedback the better will be employee productivity.

\subsection{Recommendations}

The study makes the following recommendations.

- There is a need for the management and the governing committees to explain the value and importance of performance appraisal; why is it carried, what is to be achieved as well as management expectations from employees. This helps employees to have buy-in from conception to completion; hence it would be natural for employees to adopt the system, as they will be part and parcel of the system. Further, performance appraisal should be done as a process and as an on-going exercise so as to keep checks and balances rather than to carry it out where there are areas that portray deficiencies There is also need for organisations to benchmark with successful organisations that have carried out performance appraisal outside Harare, and internationally in order to adopt best practices.

- It is also of paramount importance for the Human Resources departments to foster better working relationships with employees in order to educate and update them on requirements; hence general employee productivity will be improved. Good relations also foster trust, such that performance management is viewed as a progressive tool in an organisation, not as a punitive measure.

- Human resources executives and senior management need to involve and consult workers on the importance of training and developing them as this will reduce mistakes and wastages, as well as giving confidence and motivation in executing their duties. In light of this, management can also hire training organisations to impart skills to employees so that they become competent and efficient. In addition, training can also be carried in its various forms, such as on-the-job training to new subordinates and even outside Zimbabwe so as to get the best out of employees as well as up-skilling via continuous education, especially in view of the highly dynamic ICT industry where employees have to continuously learn new skills. It is also highly recommended that employees attend ICT conferences were new information is disseminated. There is an annual ICT conference, where various local, regional and international speakers make various presentations. This could add value to employees in terms of knowledge, leading to an increase in employee productivity.

- Performance appraisal should be encouraged among the employees to express their ideas and expectations for meeting the strategic goals of the company. Performance appraisal can make the employees become aware of expectations and the consequences of their performance. Performance appraisal should lead to improved employee performance. Performance appraisal should be optimised for effective decision-making. This can lead the employees to complete their specified work and exceed their normal work performance.

- Management must appreciate that rewarding employees goes beyond salary at the end of the month but must have an inherent reward system that is clearly and broadly explained, such that employees can fully understand that if they work hard they will be rewarded accordingly. The driving force for performance management solely rests on motivation, not just financial rewards such as bonus, stock option schemes and high salaries, but non-financial rewards such as quality circles, teamwork and job rotation amongst other attributes as highlighted by Abraham Maslow when he emphasized the importance of a hierarchy of needs (1980) as it changes the behaviour employees.

- Management should strive to make communication a daily responsibility for everyone in the organisation starting with themselves and then cascading down to the lowest level personnel. If this system is in place it would help them in communicating with employees on how they would have fared and it would be easier for subordinates to accept and correct areas needing to be assessed, and it will facilitate giving positive feedback as needed in order to reinforce positive actions. A transparent system makes it easier for employees to embrace recommendations and work on them, without the process being viewed as just being punitive and a tool to deprive them of rewards. For feedback to bear results, there is need to give timeous feedback, if the performance management process is to be meaningful. Delays negate the gains from the process, leading to the process being viewed as useless. 


\subsection{Conclusions}

The conclusions drawn from the study were as follows:

\subsubsection{Importance of performance appraisal in relation to employee productivity}

Based on the findings from the survey, the study concluded that performance appraisal did have much of an impact on the improvement of employee productivity, to a larger extent. Quite a number of employees actually regarded performance appraisal as being important in improving productivity. Therefore, an effective appraisal system can lead to an improvement in motivation and performance of the employees, ultimately leading to the completion of specified tasks or for attaining or exceeding specified performance targets.

\subsubsection{Impact of training and development on employee productivity}

It was ascertained by the study that training and development programmes were doing much in terms of improving employee productivity since most training programs were drafted as a direct outcome of performance appraisal.

\subsubsection{Importance of reward management systems on employee productivity}

The conclusion drawn from the study indicates that most ICT companies in Harare were offering various forms of rewards. This effectively means that overall organisational productivity is affected in that the greater number of employees are motivated, which affects employee productivity. Rewards in the form of bonuses lead to greater task interest and performance. Job promotion can also improve employee performance in the organisation. 5.4.4 Performance appraisal feedback on employee productivity

The survey revealed that feedback to employees' post-performance appraisal is generally very poor, such that there is uncertainty about areas needing improvement. This leads to demotivation, low morale and low productivity. It is essential to communicate and clearly explain the purpose of the appraisal process for enhanced productivity. An effective performance feedback reflects the contribution of the individual employee performance and their level of efficacy in the attainment of the organisation goals.

\subsection{Further studies}

The study recommends further studies on the performance management systems on employee productivity especially with reference to performance appraisal, training and development. The study recommends longitudinal studies so as to establish the impact performance management systems on employee productivity over a longer term since the study was done in just six months, which brings into question the representativeness and accuracy of the data. In addition, focusing on ten technological companies in Harare may only provide results that are not so accurate, as it may not truly represent all the technological companies. Similar studies may be conducted in other cities outside Harare, and possibly compare. Increasing the geographical reach of the study to other cities in order to improve the representativeness and accuracy of the findings was recommended.

\section{REFERENCES}

Jacobsen, C.B. \& Andersen, L.B. (2014). performance management in the public sector: does it decrease or increase innovation and performance? International Journal of Public Administration Vol. 37, Iss. 14.

Watkins, R. \& Leigh, D. (2012). Handbook of improving performance in the workplace: Volume 2: The handbook of selecting and implementing performance interventions. Pfeiffer: Charlotte, North Carolina.

Jagoda K., Lonseth R. \& Lonseth A. (2013). A bottom - up approach for productivity measurement and improvement. International Journal of Productivity and Performance Management, Vol. 62 Issue: 4.

Machingambi S., Maphosa C., Ndofirepi A., Mutekwe E., \& Wadesango, (2013). Perceived challenges of implementing the performance management system in Zimbabwe. Journal of Social sciences. 35. 263-271.

Zungura, M. (2014). Understanding new public management within the context of Zimbabwe. Journal of Governance and Regulation Volume 3, Issue 2, 2014.

Wachira, J.M. (2013). Relationship between Employee Engagement and Commitment in Barclays Bank of Kenya. Master's Thesis, School of Business, University of Nairobi.

Agha, N. \& Onyeizugbe, C. (2011); Reward management and organizational performance, Nigerian Journal of Business, 5(1).

Salau, O. P., Oludayo, F. O. \& Omoniy, O. C. (2014). Modeling the relationship between performance appraisal and organizational productivity in Nigerian public sector. Economic Management Innovation Journal 6 (2), 2-16.

Idemobi E.I. \& Akam G.U. (2010). The problem of managing entrepreneurial organizations for optimal performance in a competitive business environment: A critical review of early productivity improvement theories. International Journal of Entrepreneurship and Small Business Development Vol. 1 No 1.

Gichuhi, A. W., Abaja, P.O., \& Ochieng, I. (2014). Effect of performance appraisal on employee productivity: A case study of supermarkets in Nakuru Town, Kenya. Asian Journal of Business and Management Sciences 2 (11), 42-58.

Batool, S.A., \& Zulfiqar, S. (2011). The performance and structure of small \& medium enterprises: An empirical 
evidence from Pakistan. Pakistan Journal of Social Sciences (PJSS), 31(2), 433-447.

Safdar, R., Waheed, A., \& Rafiq, K. H. (2011). Impact of job analysis on job performance: Analysis of a hypothesized model. Journal of Diversity Management (JDM), 5(2).

Colville, K., \& Millner, D. (2011). Embedding performance management: understanding the enablers for change. Strategic HR Review, 10(1), 35-40.

Muhammad, S.A., Shahid, R., Muhammad, T.M. \& Ehtesham, U.L.M. (2011). E-banking: A case study of Askari Commercial Bank Pakistan. Management and Marketing Journal, University of Craiova, Faculty of Economics and Business Administration, vol. 0(2), pages 243-254, November.

Daniels, A.C. (2014). Performance management: Changing behavior that drives organizational effectiveness. 5th ed. Performance Management Publications.

Chiang, F. \& Birtch, T. (2010). Appraising performance across borders: An empirical examination of the purposes and practices of performance appraisal in a multi-country context. Journal of Management Studies, 47(7), 1365-1393.

Boselie, P.; Dietz, G. \& Boon, C. (2015). Commonalities and contradictions in HRM and performance research. Human Resource Management Journal, Vol. 15, No. 3, 67-94.

Dobre, O.I. (2013). Employee motivation and organizational performance. Review of Applied Socio-Economic Research, 2013, Vol. 5, No.1, 53-60.

Tripathi, K., \& Agrawal, M. (2014). Competency based management in organizational context: A literature review. Global Journal of Finance and Management. Vol.6, No.4, 349-356.

Vroom, V.H. (1964). Work and motivation. New York: Wiley.

Locke, E.A. (1968). Towards a theory of task motivation and incentives. Organizational Behavior and Human Performance, 3, 157-189.

Deutsch-Salamon, S. \& Robinson, S.L (2011). Trust that binds: The impact of collective felt trust on organizational performance. The University of British Columbia.

Hafiza N. S., Shah S. S., Jamsheed H. \& Zaman K. (2011). Relationship between rewards and employee's motivation in the non-profit organizations of Pakistan. Business Intelligence Journal-July.

Selden S, Jessica E. Sowa, (2011). Performance management and appraisal in human service organizations: Management and staff perspective. Public Personnel Management. 40. 251-264. $10.1177 / 009102601104000305$.

Kabak, E., Gocer, K. Kucuksoylemez, S., \& Tuncer, G (2014). Strategies for employee job satisfaction: a case of service sector. Procedia - Social and Behavioral Sciences Vol. 150, 1167 - 1176.

Hunter, D.E.K. \& Nielsen, S.B. (2013). Performance management and evaluation: Exploring complementarities. Performance Management and Evaluation, Spring. pp 7-17.

Kiechel, W. (2010). The lords of strategy: The secret intellectual history of the new corporate world. Boston: Harvard Business Press.

Schultz, W. (2006). Behavioral theories and the neurophysiology of reward. Annual Review of Psychology Vol. 57: pp. 87-115.

Latham, G.P., Borgogni, L. \& Petitta, L. (2008). Goal setting and performance management in the public sector, International Public Management Journal, 11:4, 385-403, DOI: 10.1080/10967490802491087

Cook, J. \& Crossman, A. (2004). Satisfaction with performance appraisal systems: A study of role perceptions, Journal of Managerial Psychology, Vol. 19 Issue: 5, pp. 526-541.

Dechev, Z. (2010). Effective performance appraisal: A study into the relation between employer satisfaction and optimizing business results. Faculty of Economics of Business Department of Economics.

Madison, J. (2016). Performance management revolution. Harvard Business review: October 2016 issue.

Singh, V.K., Kochar, B. \& Yüksel, S. (2010). An empirical study on the efficiency of performance appraisal system in oil and natural gas commission (ONGC). India İşletme Araştırmaları Dergisi 2/2 65-78.

Bahrija Umihanic, B., Herzegovina, \& Mirela Cebic (2013). Functions of the performance appraisal system: Analyses and their impact on level of employees' motivation. International Journal of Sustainable Economies Management, 1(1): 1-15.

Lambert, D.M. (2009). Customer relationship management as a business process. Department of Marketing and Logistics, Fisher College of Business, The Ohio State University, Columbus, Ohio, USA.

Ubeda, C.L., \& Santos, F.C. (2013). Staff development and performance appraisal in a Brazilian research Centre. European Journal of Innovation Management, 10(1): 109-125.

Shaukat, M.M. \& Surrayya Aslam (2013). Performance appraisal and employee motivation. A comparative analysis of telecom industry in Pakistan. Pakistan Journal of social Sciences (PJSS) Vol. 33, No.1 pp. 179189.

Mohammad, H. K., Mehrzad, H., Mahmoud, G., \& Mohammad, H. (2012). Identification of organizational factors associated with IOC employees performance based on wise board model. International Journal of Academic Research in Business and Social Sciences, 2 (6), 396-204. 
Esu, B.B. \& Inyang, B.J. (2009). A case for performance management in the public sector in Nigeria. International Journal of Business and Management. Vol 4. p. 98.

Demerouti, E. \& Cropanzano, R. (2010). From thought to action: Employee work engagement and job performance. In A. B. Bakker and M. P. Leiter (Eds.), Work engagement: A handbook of essential theory and research, (pp. 147-163), Hove, East Sussex: Psychology Press.

Idemobi, E. \& Onyeizugbe, C. (2011). Performance management as an imperative for effective performance in delta state of Nigerian public owned organizations. Sacha Journal of Policy and Strategic Studies, Volume 1 Number 2 (2011), p. 46-54

Lawler, E.E. (2008). Make human capital a source of competitive advantage. Marshall School of Business Working Paper No. MOR 16-09

Sajuyigbe, A.S., Olaoye Bosede, O., \& Adeyemi, M.A. (2013). Impact of reward on employees' performance in a selected manufacturing companies in Ibadan, Oyo State, Nigeria, p.29.

Akhtar, T \& Khattak, S. (2013). Employee acceptability of performance appraisals: Issues of fairness and justice. World Applied Sciences Journal. 24. 507-518. 10.5829/idosi.wasj.2013.24.04.241.

Ajila, C. \& Abiola, A. (2004). Influence of rewards on workers performance in an organisation. Journal of Social Science, 8, 7-12.

Aktar, S. (2012). The impact of rewards on employee performance in commercial banks of Bangladesh: An empirical study. IOSR Journal of Business and Management. 6. 9-15. 10.9790/487X-0620915.

Tahir, Neelam \& Khan Yousafzai, Israr \& Shahid Jan, Dr \& Hashim, Muhammad. (2014). The impact of training and development on employees performance and productivity: A case study of United Bank Limited Peshawar City, KPK, Pakistan. International Journal of Academic Research in Business and Social Sciences. 4. 10.6007/IJARBSS/v4-i4/756.

Aarti, C., Seema, C., Bhawna, C. \& Jyoti, C. (2013). Job satisfaction among bank employees: An analysis of the contributing variables towards job satisfaction. International Journal of Scientific \&Technology Research, 2(8), 11-20.

Stone, D.L., Stone-Romero, E.F. \& Lukaszewski, K. (2006). Factors affecting the acceptance and effectiveness of electronic human resource systems, Human Resource Management Review, Vol. 16, No. 2, pp. 229-244.

Brown (2011) Brown, G. \& Edmunds, S. (2011). Doing Pedagogical research in Engineering. Leicestershire, England: eng CETL, p13-109.

Danish, R. \& Usman, A. (2010). Impact of reward and recognition on job satisfaction and motivation: An empirical study from Pakistan. International Journal of Business and Management. 5. $10.5539 / \mathrm{ijbm} . v 5 \mathrm{n} 2 \mathrm{p} 159$.

Randell, F. (2014). Issues and challenges in the practice of performance appraisal activities in the 21 st century. International Journal of Education and Research 1 (4), 1-8.

Farooqui, S., \& Nagendra, A., (2014). The impact of person organization fit on job satisfaction and performance of the employees. Procedia Economics and Finance, Vol. 11, 122 - 129.

Shaheen, A., Naqvi, S.M.H. \& Khan, M.A. (2013). Employees training and organizational performance: Mediation by employees performance. Interdisciplinary Journal of Contemporary Research in Business, 5 (4), 490-503.

Rubin, A. \& Babbie, E. R. 2010. Research methods for social work. Belmont, US: Brooks Cole.

Saunders, M., Lewis, P. \& Thornhill, A., 2012. Research methods for business students, 6th ed. Edinburgh: Pearson Education Limited.

Collis J. \& Hussey, R., (2011). Business research: A practical guide for undergraduate and postgraduate student, $3^{\text {rd }}$ edition. Palgrave Macmillan.

Hair, J., Babin, B., Money, P. \& Samouel, P. (2011). Essential of business research methods. USA: Wiley.

Bryman, A. \& Bell, E. (2011). Business research methods, OUP: Oxford.

Brown, G. \& Edmunds, S. (2011). Doing pedagogical research in engineering. Leicestershire, England: eng CETL, p13-109.

Wiid, J. \& Diggines, C. (2011). Marketing research. Cape Town: Juta \& Company Ltd.

Oppenheim, A. (2014). How to define and evaluate research in education. NY: McGraw-Hill Publishers.

Techzim. 2017). Zimbabwe telecoms reports by POTRAZ. Available: https://www.techzim.co.zw/zimbabwepotraz-telecoms-reports/; [Accessed: 4 July 2017].

Denzin, N. K., \& Lincoln, Y. S. (2011). The Sage handbook of qualitative research (4 ${ }^{\text {th }}$ ed.). Thousand Oaks, CA: Sage Publications, Inc.

Kitchenham, B. \& Pfleeger, S.L. (2012). Principles of survey research: part 5: Populations and samples $A C M$ SIGSOFT Software Engineering Notes Volume 27 Issue 5, September 2002 Pages 17-20

Kothari, R. (2011). Research methodology: Methods \& techniques. Delhi: New Age International.

Creswell, J.W. (2013). Qualitative inquiry and research design: Choosing among five approaches $3^{\text {rd }}$ ed. Los Angeles: SAGE Publications. 
Gupta, A. \& Upadhyay, D. (2012). Impact of effectiveness of performance management system on employee satisfaction and commitment. International Journal of Management, IT and Engineering, 2(7).

Martinho, J., Gomes, F. \& Mahmoud, C. \& Y. (2015). Enhancing organisational performance through information technology: An organisational and social strategic context. International Journal of Business Information Systems. 20. 95. 10.1504/IJBIS.2015.070887. 